\title{
Metallothermic Production of Boron-containing Silicon Barium
}

\section{Alexandr Abdulovich Akberdin and Meirzhan Meiramovich Karbayev}

Chemical-metallurgical institute named after Zhantore Abishev, Karaganda, Republic of Kazakhstan

\section{Abstract}

Silicon barium is an effective modifier for ferrous and non-ferrous metals. In Kazakhstan, it is produced at the Aksu Ferroalloy Plant, but its smelting volumes are significantly lower than those of traditional ferroalloys, moreover, it is melted only to order. To improve the consumer properties of silicon barium, we proposed to introduce boron to it, possessing a high effect of a positive impact on the quality of metals at low (0.001$0.003 \%$ ) concentrations. The core of the proposed technology is reduced to pouring out silicon barium from the ore-smelting furnace into a ladle with boron-containing oxide

Corresponding Author: Meirzhan Meiramovich Karbayev meirzhan_92.kz@mail.ru

Received: 5 February 2019 Accepted: 6 March 2019 Published: 17 March 2019 Publishing services provided by Knowledge $\mathrm{E}$

(c) Alexandr Abdulovich Akberdin and Meirzhan Meiramovich Karbayev. This article is distributed under the terms of the Creative Commons Attribution License, which permits unrestricted use and redistribution provided that the original author and source are credited.

Selection and Peer-review under the responsibility of the NIOKR-2018 Conference Committee. material. Silicon and barium of the molten metal were assumed to reduce boron from $\mathrm{B}_{2} \mathrm{O}_{3}$ in accordance with such reactions, for instance: $4 \mathrm{Si}+2 \mathrm{~B}_{2} \mathrm{O}_{3}=\mathrm{B}_{4} \mathrm{Si}+3 \mathrm{SiO}_{2}$ and $10 \mathrm{Ba}+3 \mathrm{~B}_{2} \mathrm{O}_{3}=\mathrm{BaB}_{6}+9 \mathrm{BaO}$. We have carried out a complete thermodynamic analysis of the proposed technology using the TERRA software package, having enriched its database with the compounds anticipated in the products of smelting. A possibility of fulfilling the technology in principle has been established. It has been found that a share of barium participation in the recovery processes increases with increasing its concentration in the metal being poured off from the furnace. The experiments using an industrial sample of ferrosilicobarium have been carried out in a high-temperature laboratory furnace. The recovery of boron was within the limits of $48-71 \%$, showing its progressive fall while attempting to obtain a metal with a higher boron content. Judging by the weight loss of reducing agents in the metal being poured off, barium is the main participant in the process. Based on thermodynamic and physical simulation, we have made a conclusion on the possibility to obtain a boron-containing silicobarium by the metallothermic method in a ladle and necessity to carry out industrial testing.

Keywords: modification, silicon barium, boron, ladle

\section{Introduction}

Modification and microalloying are an effective means of enhancing the performance S OPEN ACCESS 
has a low solubility in iron $(0.0003 \%)$ and to overcome this threshold it is produced in the form of alloys with silicon or aluminum. In the first case, well-soluble silicide (BaSi, $\left.\mathrm{BaSi}_{2}\right)$ are formed in iron and therefore such alloys are called silicon barium or ferrosilicon with barium. Due to the joint efforts of the Russian and Kazakh specialists, the production of such alloys was established at the Yermakovsky (now Aksu) ferroalloy plant [1-5]. But the production volumes of silicon barium are much lower than those of traditional ferroalloys and melt it in the presence of orders. To increase the consumer properties of silicon barium, exploratory studies have been conducted on the introduction of boron into it, given the high effect of its positive influence on the quality of ferrous metals at low $(0.001-0.003 \%)$ concentrations $[6,7]$. The essence of the technology is merging from the ore-smelting furnace of silicon barium into the ladle with boron-containing oxide material. This method of production of boron-containing ferrosilicon under the guidance of professor Zhuchkova V.I. was developed and successfully used at the Serov Ferroalloy Plant $[8,9]$.

\section{Modeling Silicon Barium with Boron using the TERRA Software Package}

In the present work, it was assumed that silicon and barium of molten metal will reduce boron from $\mathrm{B}_{2} \mathrm{O}_{3}$ borate ore:

$$
\begin{array}{cc}
3 \mathrm{Si}+2 \mathrm{~B}_{2} \mathrm{O}_{3}=4 \mathrm{~B}+3 \mathrm{SiO}_{2} & \Delta \mathrm{G}_{1973 \mathrm{~K}}=-34,4 \mathrm{~kJ} / \mathrm{mol} \\
4 \mathrm{Si}+2 \mathrm{~B}_{2} \mathrm{O}_{3}=\mathrm{B}_{4} \mathrm{Si}+3 \mathrm{SiO}_{2} & \Delta \mathrm{G}_{1973 \mathrm{~K}}=-60,5 \mathrm{~kJ} / \mathrm{mol} \\
11 \mathrm{Si}+6 \mathrm{~B}_{2} \mathrm{O}_{3}=2 \mathrm{~B}_{6} \mathrm{Si}+9 \mathrm{SiO}_{2} \quad \Delta \mathrm{G}_{1973 \mathrm{~K}}=-172,8 \mathrm{~kJ} / \mathrm{mol} \\
23 \mathrm{Si}+14 \mathrm{~B}_{2} \mathrm{O}_{3}=2 \mathrm{SiB}_{14}+21 \mathrm{SiO}_{2} \quad \Delta \mathrm{G}_{1973 \mathrm{~K}}=-271,5 \mathrm{~kJ} / \mathrm{mol} \\
3 \mathrm{Ba}+\mathrm{B}_{2} \mathrm{O}_{3}=3 \mathrm{BaO}+2 \mathrm{~B} \quad \Delta \mathrm{G}_{1973 K}=-262,2 \mathrm{~kJ} / \mathrm{mol} \\
10 \mathrm{Ba}+3 \mathrm{~B}_{2} \mathrm{O}_{3}=\mathrm{BaB}_{6}+9 \mathrm{BaO} & \Delta \mathrm{G}_{1973 \mathrm{~K}}=-1016,5 \mathrm{~kJ} / \mathrm{mol}
\end{array}
$$

In the expectation of obtaining 1 mole of boron, the average value of the Gibbs energy change in silicon reduction reactions (1) - (6) is $11.9 \mathrm{~kJ} / \mathrm{mol}$, and barium (5), (6) - 150.3 $\mathrm{kJ} / \mathrm{mol}$. It can be concluded that silicon, especially barium, will vigorously reduce boron. But in conditions of real smelting, besides those indicated above, other reactions may occur that can change the process. 
For this reason, we performed a complete thermodynamic analysis of the proposed technology at a temperature of 1973K using the TERRA software [10], replenishing its database with the compounds expected in the smelting products [11,12]. The composition adopted for the calculation of the initial metals merging from the furnace is shown in Table 1.

TABLE 1: The chemical composition of the initial alloys.

\begin{tabular}{|l|c|c|c|}
\hline No. $^{\circ}$ & \multicolumn{3}{|c|}{ Element content, g } \\
\hline & Fe & Si & Ba \\
\hline 1 & 34 & 65 & 1 \\
\hline 2 & 33 & 65 & 2 \\
\hline 3 & 30 & 65 & 5 \\
\hline
\end{tabular}

The composition of the planned to obtain metals is shown in Table 2.

TABLE 2: The chemical composition of the planned alloys production.

\begin{tabular}{|l|l|l|l|l|}
\hline N. & \multicolumn{4}{|c|}{ Element content, g } \\
\hline & Fe & Si & Ba & B \\
\hline 1 & 33 & 65 & 1 & 1 \\
\hline 2 & 32 & 65 & 1 & 2 \\
\hline 3 & 31 & 65 & 1 & 3 \\
\hline 4 & 32 & 65 & 2 & 1 \\
\hline 5 & 31 & 65 & 2 & 2 \\
\hline 6 & 30 & 65 & 2 & 3 \\
\hline 7 & 29 & 65 & 5 & 1 \\
\hline 8 & 28 & 65 & 5 & 2 \\
\hline 9 & 27 & 65 & 5 & 3 \\
\hline
\end{tabular}

Pure $\mathrm{B}_{2} \mathrm{O}_{3}$ was used as a boron source. The calculations on the software package TERRA give the phase composition of the smelting products. Then it was counter on element. The composition of the obtained metal for all nine variants of the calculation is shown in Table 3.

It can be seen that with the bucket method, high boron extraction is achieved. Both silicon and barium are involved in this, which can be seen from the loss of their weight at the end of the process. Moreover, at low levels of barium in the starting metal (1-2\%), its participation in recovery processes is significantly inferior to silicon, increasing at high (alloys 7-9, Table 3). 
TABLE 3: Chemical composition of metal.

$\mathbf{N}^{\circ}$.

1
2
3
4
5
6
7
8
9

\begin{tabular}{|c|}
\hline $\mathrm{Fe}$ \\
\hline 34 \\
\hline 34 \\
\hline 34 \\
\hline 32,9 \\
\hline 33 \\
\hline 33 \\
\hline 30 \\
\hline 29,9 \\
\hline 29,9 \\
\hline
\end{tabular}

Element content, $\mathrm{g}$

\begin{tabular}{c}
$\mathbf{S i}$ \\
63,05 \\
66,10 \\
59,15 \\
63,05 \\
\hline 61,11 \\
\hline 59,14 \\
\hline 63,34 \\
\hline 61,18 \\
\hline 59,15 \\
\hline
\end{tabular}

\begin{tabular}{c}
$\mathbf{B a}$ \\
0,99 \\
0,99 \\
0,99 \\
1,99 \\
1,99 \\
\hline 1,99 \\
\hline 4,11 \\
\hline 4,23 \\
4,26 \\
\hline
\end{tabular}

B
0,98
1,98
2,99
0,99
1,99
2,99
0,99
1,98
2,97

\begin{tabular}{|c|c|}
\hline \multicolumn{2}{|c|}{ Relative decline, $\%$} \\
\hline Si & Ba \\
\hline 3 & 1 \\
\hline 6 & 1 \\
\hline 9 & 1 \\
\hline 3 & 0,5 \\
\hline 6 & 0,5 \\
\hline 9 & 0,5 \\
\hline 3 & 17,8 \\
\hline 6 & 15,4 \\
\hline 9 & 14,8 \\
\hline
\end{tabular}

Boron extraction, \% 98,0 99,0 99,7 99,0 99,5 99,7 99,0 99,0 99,0

\section{The Experiments in a Laboratory Resistance Furnace}

When using the initial metal with 10, 20 and $30 \%$ barium to obtain $2 \%$ boron in the final metal, the barium weight loss is $57.7 ; 38.1$ and $25.7 \%$. The observed can be explained by an increase in the proportion of barium in the reduction process in the merging metal, despite its connection to disilicide $\left(\mathrm{BaSi}_{2}\right)$ (Table 4) [11]. It has been carried out experiments in a laboratory resistance furnace. An industrial sample of ferrosilicobarium of the Aksu Ferroalloy Plant containing (mass\%): $15 \mathrm{Fe}, 63 \mathrm{Si}, 22 \mathrm{Ba}$ was used. There have been obtained three samples of metal of different composition (Table 5), with the addition of pure iron (Fe) and crystalline silicon (Si) into alloy.

TABLE 4: The composition of the initial ferroalloys.

\begin{tabular}{|l|c|c|c|c|c|c|c|}
\hline N.. & Alloy & \multicolumn{5}{|c|}{ The composition of the alloy, the mass, \% } \\
\hline & \multicolumn{3}{|c|}{ Chemical } & \multicolumn{3}{|c|}{ Phase } \\
\hline & Fe & Si & Ba & BaSi $_{2}$ & Si & FeSi \\
\hline 1 & ФC65 & 35 & 65 & - & - & 47,4 & 52,6 \\
\hline 2 & ФC65Ba1 & 34 & 65 & 1 & 1,4 & 47,5 & 51,1 \\
\hline 3 & ФC65Ba2 & 33 & 65 & 2 & 2,8 & 47,6 & 49,6 \\
\hline 4 & ФC65Ba5 & 30 & 65 & 5 & 7,0 & 47,9 & 45,1 \\
\hline 5 & ФC65Ba10 & 25 & 65 & 10 & 14,1 & 48,3 & 37,6 \\
\hline 6 & ФC65Ba20 & 15 & 65 & 20 & 28,2 & 49,3 & 22,5 \\
\hline 7 & ФC65Ba30 & 5 & 65 & 30 & 42,3 & 50,2 & 7,5 \\
\hline
\end{tabular}

Planned to get shown in Table 6 alloys. 
TABLE 5: The chemical composition of the initial alloys.

\begin{tabular}{|l|c|c|c|}
\hline $\mathbf{N}^{\circ}$. & \multicolumn{3}{|c|}{ Element content, mass.\% } \\
\hline & Fe & Si & Ba \\
\hline 1 & 34 & 65 & 1 \\
\hline 2 & 33 & 65 & 2 \\
\hline 3 & 30 & 65 & 5 \\
\hline
\end{tabular}

TABLE 6: Chemical composition of alloys planning for production.

\begin{tabular}{|l|c|c|c|c|}
\hline No. & \multicolumn{4}{|c|}{ Element content, mass.\% } \\
\hline & Fe & Si & Ba & B \\
\hline 1 & 33 & 65 & 1 & 1 \\
\hline 2 & 31 & 65 & 2 & 2 \\
\hline 3 & 27 & 65 & 5 & 3 \\
\hline
\end{tabular}

Reactive $\mathrm{B}_{2} \mathrm{O}_{3}$ was used as a boron source. Attempts to carry out experiments by pouring the molten metal from the furnace into a graphite crucible with boron oxide were not successful. The stock of heat of the hot metal was not enough to pass recovery processes. A porous slag-metal mixture was obtained. The reason for this is a large heat sink due to the high ratio of the cooled surface of a thin-walled crucible to its volume. Therefore, the mixture of silicobarium and $\mathrm{B}_{2} \mathrm{O}_{3}$ was briquetted and melted in the furnace at $1973 \mathrm{~K}$. The results of the experiments are shown in Table 7.

TABLE 7: The chemical composition of the experimental metal.

\begin{tabular}{|c|c|c|c|c|c|c|c|}
\hline \multirow[t]{2}{*}{$\mathbf{N}^{\circ}$. } & \multicolumn{4}{|c|}{ Content in the alloy, the masses, $\%$} & \multicolumn{2}{|c|}{ Relative decline, $\%$} & \multirow{2}{*}{$\begin{array}{l}\text { Boron } \\
\text { extrac- } \\
\text { tion, \% }\end{array}$} \\
\hline & $\mathrm{Fe}$ & Si & $\mathrm{Ba}$ & B & Si & $\mathrm{Ba}$ & \\
\hline 1 & 31,6 & 64,02 & 0,69 & 0,71 & 1,5 & 31 & 71 \\
\hline 2 & 30,6 & 60,4 & 1,5 & 1,2 & 7,1 & 25 & 60 \\
\hline 3 & 24 & 63,1 & 2,4 & 1,8 & 2,9 & 52 & 48 \\
\hline
\end{tabular}

Boron extraction was in the range of $48-71 \%$, showing its progressive fall when trying to produce metal with a high boron content. Viewing by the weight loss of reducing agents in the merging metal, barium takes the main part in the process. 


\section{Conclusion}

Thus, thermodynamic and physical modeling shows the possibility of obtaining boroncontaining silicon barium by the ladle metallothermic method. The final conclusion can be made after the planned industrial tests.

\section{References}

[1] Zhuchkov V.I. and Lukin S.V.(1990). Technology of ferroalloys with alkaline earth metals: Moscow: Metallurgy.

[2] Pankov V.A., Kozhevnikov G.N., Zhuchkov V.I., Lukin S.V. and Parfenov A.A. (1981). Production of barium-containing alloys from barite ores: KIMS. № 11. - p. 63-67.

[3] Borodaenko L.N., Takenov, T.D. and Gabdullin, T.G. (1990). Electrothermia of complex alloys with active elements. Gylym: $120 \mathrm{p}$.

[4] Berdnikov V.I., Gudim Yu.A. and Karteleva M.I. (2007).Thermodynamic modeling of the process of obtaining silicon barium. Izv. universities. Ferrous metallurgy. № 10. p. 23-25.

[5] Grigoriev, Yu.V., Ryabchikov, I.V. and Roshchin, V.E. (2005). Thermodynamic analysis of the joint reduction of silicon and barium by carbon. Izv. universities. Ferrous metallurgy. - № 7. p. 3-5.

[6] Lyakishev, I. P., Pliner, Yu. L. and Lappo, S. I. (1986). Boron-containing steels and alloys. Moscow. Metallurgy.

[7] Parusov V.V., Parusov E.V. and Sychkov A.B. (2010). Boron steel for high strength fasteners. Dnepropetrovsk, Art-PRESS.

[8] Zhuchkov V.I.(2015). Research and improvement of the process of obtaining complex boron-containing ferroalloys/V.I. Zhuchkov, A.V. Sychev, A.A. Akberdin, E.A. Trofimov, V.A. Salina, A.A. Babenko// in Proceedings Materials of the XVI Int. Conference, Chelyabinsk.

[9] Eurasian Patent No. 020687. A method of obtaining a complex boron-containing alloy based on silicon. Zhuchkov V.I., Selivanov E.N., Zayakin O.V., Sychev A.V., Akberdin A.A., Kim A.S., Ostrovsky Ya.I., Fadeev V.I. From 07.10. Bul. izob. № 5. 2015

[10] Trusov B.G. (2002). The TERRA software system for modeling phase and chemical equilibria in plasma-chemical systems, in Proceedings 3rd International Symposium on Theoretical and Applied Plasma Chemistry. Ivanovo. Sat materials. 
[11] Akberdin A.A., Karbaev M.M., Kim A.S. andcSultangaziev R.B. (2016). Construction and mathematical description of the diagram of the phase composition of the system $\mathrm{Fe}-\mathrm{Si}$ - Ba - B. in Proceedings Mendeleev Congress, Ekaterinburg.

[12] Karbaev M.M. and Akberdin A.A.(2016). Mathematical model of the phase diagram of the composition of the system $\mathrm{BaO}-\mathrm{SiO}_{2}-\mathrm{B}_{2} \mathrm{O}_{3}$. Works of the University of Karaganda, № 4, pp.26- 